\title{
Characterization of intraepithelial lymphocytes in human endometrium
}

\author{
Denise Pace, Margaret Longfellow and Judith N. Bulmer \\ Department of Pathology, University of Leeds, Leeds LS2 9JY, UK
}

\begin{abstract}
Summary. Intraepithelial lymphocytes (IELs) were characterized and quantitated in normal non-pregnant endometrium and in early pregnancy decidua using $\mathrm{H} \& \mathrm{E}$ and phloxine tartrazine stains and a panel of monoclonal antibodies in an indirect immunoperoxidase technique. The relative numbers of granulated and non-granulated IELs varied according to menstrual cycle stage and in early pregnancy all IELs appeared to be granulated. There was a higher surface:gland ratio for IELs in proliferative endometrium compared with late secretory phase and early pregnancy endometrium. In proliferative endometrium most IELs were T cells, predominantly of the CD8 + subset. In first trimester decidua, higher numbers of CD56 + cells were observed, in keeping with the increased proportion of granulated IELs. IEL populations in human endometrium vary according to menstrual cycle stage and endometrial IELs appear to show phenotypic differences compared with IELs in the human gastrointestinal tract.
\end{abstract}

Keywords: endometrium; lymphocytes; intraepithelial; immunohistochemistry; man

\section{Introduction}

The concept of mucosal immunity is well recognized and has been documented in the gastrointestinal system (Parrott, 1976), skin (Patterson \& Edelson, 1982), and bronchus (Bienenstock et al., 1973). The major intraepithelial lymphocyte (IEL) population in human gut consists of CD3 $+\mathrm{T}$ cells, almost exclusively CD8 + suppressor/cytotoxic type in the small intestine and approximately equal CD8 + and CD4 + cells in the large intestine (Trejdosiewicz et al., 1987).

In general, the mucosal-associated lymphoid tissue (MALT) system forms part of the peripheral lymphoid tissue and is present at epithelial sites which are either fully or potentially exposed to environmental antigens. Mucosal immunity in human endometrium has been studied surprisingly rarely and does not appear to exhibit the hallmarks of MALT elsewhere in the body. The endometrium does not possess a classical secretory immune system as seen in the gastrointestinal tract; indeed, the presence of plasma cells in the endometrium is regarded as pathological. Endometrial epithelial cells in the secretory phase of the menstrual cycle do have the ability to extract polymeric IgA from plasma via secretory component and this may protect the mucosa from infection (Kelly \& Fox, 1979; Bulmer et al., 1986). The endometrium contains various leucocyte populations (Morris et al., 1985; Kamat \& Isaacson, 1987; Bulmer et al., 1988; Marshall \& Jones, 1988; King et al., 1989) comprising (i) IELs, (ii) interstitial stromal lymphocytes and macrophages and (iii) lymphoid aggregates in the stratum basalis. The aim of this study was to document the presence and phenotype of granulated and non-granulated IELs in human endometrium.

\section{Materials and Methods}

Tissues. Routine formalin-fixed haematoxylin and eosin (H \& E) stained sections of normal endometrium from hysterectomy specimens were extracted from the files of the University Department of Pathology, Leeds. Endo- 
metrium from all stages of the menstrual cycle was chosen (proliferative $=20$; secretory $=30$ ). Eight cases of early pregnancy decidua were similarly selected, 3 from pregnancy hysterectomies and 5 from elective aspiration pregnancy terminations. The sections were reviewed to confirm that histology was appropriate for menstrual dates and further $4 \mu \mathrm{m}$ sections were stained with phloxine-tartrazine and the monoclonal antibody (mAb) Dako-LC to demonstrate the phloxinophilic cytoplasmic granules of granulated IELs and cells reactive with the leucocyte common antigen (CD45), respectively.

Fresh fragments of decidua, identified by their opaque grey-white macroscopic appearance, were recovered from elective first trimester aspiration terminations (4 cases) of apparently normal pregnancies. Fresh tissue was also available from 4 pregnancy hysterectomies of 8-11 weeks gestational age. Fresh normal, non-pregnant endometrium was obtained from curettage or hysterectomies (proliferative $=10$ cases; secretory $=18$ cases). The tissue fragments of 5-10 $\mathrm{mm}^{3}$ were snap-frozen in liquid nitrogen-cooled isopentane (BDH, Poole, Dorset, UK) and stored in liquid nitrogen until sectioned. Cryostat sections were cut at 5-7 $\mu \mathrm{m}$, air dried overnight and fixed for $10 \mathrm{~min}$ in acetone at room temperature. Sections were wrapped in aluminium foil and stored at $-20^{\circ} \mathrm{C}$ until use.

Antibodies. Eight separate mAbs were used in the study and dilutions, specificities and sources are detailed in Table 1.

Table 1. Primary monoclonal antibodies

\begin{tabular}{|c|c|c|c|}
\hline Monoclonal & Source & Specificity & Dilution \\
\hline Dako-LC & $\begin{array}{l}\text { Dakopatts, } \\
\text { High Wycombe } \\
\text { Bucks, UK }\end{array}$ & $\begin{array}{l}\text { Leucocyte common } \\
\text { antigen: CD45 }\end{array}$ & $1: 10$ \\
\hline UCHT1 & $\begin{array}{l}\text { Oxoid, } \\
\text { Bedford, UK }\end{array}$ & $\mathrm{CD} 3$ & $1: 50$ \\
\hline Dako-T1! & Dakopatts & $\begin{array}{l}\text { E-rosette } \\
\text { receptor: CD2 }\end{array}$ & $1: 50$ \\
\hline Dako-T8 & Dakopatts & CD8 & $1: 20$ \\
\hline Leu-11b & $\begin{array}{l}\text { Becton-Dickinson, } \\
\text { Mountain View } \\
\text { CA, USA }\end{array}$ & CD16 & $1: 20$ \\
\hline NKH1 & $\begin{array}{l}\text { Coulter Clone, } \\
\text { Luton } \\
\text { Bedfordshire } \\
\text { UK }\end{array}$ & CD56 & $1: 100$ \\
\hline $\mathrm{FMC17}$ & $\begin{array}{l}\text { Sera-lab, } \\
\text { Crawley Down } \\
\text { Sussex, UK }\end{array}$ & CD14 & $1: 10$ \\
\hline DA6.231 & Dr C.M. Steel & $\begin{array}{l}\text { Class II MHC } \\
\text { non-polymorphic } \\
\text { determinant }\end{array}$ & $1: 10$ \\
\hline T10 & $\begin{array}{l}\text { Serotec } \\
\quad \text { Bicester } \\
\text { Worcs, UK }\end{array}$ & CD38 & $1: 100$ \\
\hline Anti-IL2 receptor & Coulter Clone & $\mathrm{CD} 25$ & $1: 100$ \\
\hline Dako-Pan-B & Dakopatts & $\mathrm{CD} 22$ & $1: 10$ \\
\hline
\end{tabular}

Immunohistochemistry. Standard indirect immunoperoxidase methods were used to label paraffin wax-embedded and fresh tissues with the mAbs in Table 1. Details of the methods have been described previously (Sunderland et al., 1981). Peroxidase-conjugated rabbit anti-mouse immunoglobulin was purchased from Dakopatts (High Wycombe, Bucks, UK). The reaction was developed with 3,3'-diaminobenzidine (DAB). Selected sections were also labelled with a streptavidin-biotin-peroxidase kit (Zymed, San Francisco, CA, USA). The sections were incubated sequentially with the primary $\mathrm{mAbs}(30 \mathrm{~min})$, biotinylated anti-mouse immunoglobulin $(10 \mathrm{~min})$ and streptavidin-peroxidase ( $5 \mathrm{~min}$ ) as per the supplier's instructions. The reaction was developed with the supplied aminoethyl carbazole (AEC) to give a red reaction product.

Standard controls were performed at all levels for both the indirect immunoperoxidase and streptavidin-biotinperoxidase methods. Sections were lightly counterstained with haematoxylin and mounted in synthetic resin (DAB) or aqueous mountant (AEC). 
Quantitation. Phloxine-tartrazine-stained sections of stratum functionalis of cyclic endometrium and early pregnancy decidua compactum were scanned over 10 high-power fields $(\times 10$ eyepiece, $\times 40$ objective $)$ and the number of IELs with phloxinophilic cytoplasmic granules/10 fields was recorded (Fig. 1). Each field necessarily had to contain glandular structures or surface epithelium in order to assess the number of granulated IELs. A granulated lymphocyte was recorded as intraepithelial if clearly flanked by two epithelial cells and situtated above the epithelial basement membrane. A similar method was used to assess the number of IELs reactive with Dako-LC (Fig. 2). The mean number of IELs/ 10 fields for each stage of the cycle and in early pregnancy was calculated. The numbers of IELs (both granulated and CD45+) in the different stages of the cycle and in early pregnancy were compared using the KruskalWallis test.

To calculate the surface:gland ratio of IELs within each individual specimen the numbers of CD45+ IELs were counted per 150 epithelial cells, both within the surface epithelium and within the glands (Fig. 2). The mean values for different cycle stages were compared using the Kruskal-Wallis test.

Sections of frozen endometrium and early pregnancy decidua were studied using the mAbs in Table 1. All CD45+ IELs were counted in the entire section for each case. The number of macrophages was evaluated by counting intraepithelial cells reactive with DA6.231 and anti-CD14 (Fig. 2). DA6.231 + cells were generally irregular in shape. The $\mathrm{mAb}$ which gave the highest number of intraepithelial macrophages was used to calculate the number of intraepithelial lymphocytes per section by subtracting that number from the number of Dako-LC-reactive cells. The number of intraepithelial cells per section reacting with the other mAbs was counted and represented as a percentage of the total number of IELs. These percentages were then expressed as a mean value for each cycle phase and statistical analysis was carried out using the Kruskal-Wallis test.

\section{Results}

\section{Paraffin wax-embedded sections}

Low numbers of granulated IELs were detected in proliferative and early secretory endometrium; they increased in frequency in the late secretory phase and stayed at similar levels in early pregnancy decidua (Table 2). There was a significant increase in granulated IELs between proliferative and late secretory phases $(P<0.0001)$ and between proliferative endometrium and early pregnancy decidua $(P<0.009)$ (Table 2$)$. The increase between early and late secretory phases was also significant $(P<0.01)$ but there was no significant difference between early secretory endometrium and first trimester decidua.

Table 2. Mean numbers of granulated and non-granulated intraepithelial lymphocytes

\begin{tabular}{|c|c|c|c|c|c|c|c|c|}
\hline \multirow[b]{2}{*}{ Cycle stage } & \multirow{2}{*}{$\begin{array}{l}\text { No. of } \\
\text { samples }\end{array}$} & \multicolumn{3}{|c|}{ Granulated IELs/10 fields } & \multicolumn{3}{|c|}{ CD45 + IELs $/ 10$ fields } & \multirow{2}{*}{$\begin{array}{c}\text { Mean \% } \\
\text { granulated } \\
\text { IELs/CD45 + IELs }\end{array}$} \\
\hline & & Mean & s.e.m. & Range & Mean & s.e.m. & Range & \\
\hline Proliferative & 20 & 1.90 & 0.35 & 06 & $7 \cdot 95$ & $1 \cdot 14$ & $1-18$ & $24 \cdot 5$ \\
\hline Early secretory & 15 & $2 \cdot 67$ & 0.73 & $<1-9$ & $10 \cdot 10$ & 1.73 & $3-23$ & $26 \cdot 3$ \\
\hline Late secretory & 15 & $5 \cdot 67$ & 0.99 & $1-12$ & $12 \cdot 20$ & 1.53 & $4-26$ & $46 \cdot 4$ \\
\hline Early pregnancy & 8 & $5 \cdot 63$ & $1 \cdot 21$ & $1-11$ & $4 \cdot 00$ & 0.92 & $1-7$ & 100 \\
\hline
\end{tabular}

The number of CD45 + IELs consistently exceeded that of granulated IELs in non-pregnant endometrium (Figs 1,2). The number of CD45+ IELs was comparable throughout the menstrual cycle but decreased in early pregnancy decidua, the number of CD45 + IELs being comparable with that of granulated IELs. There was a significant increase in numbers of CD45+ IELs from proliferative to late secretory $(P<0.05)$ and a significant decrease in $\mathrm{CD} 45+$ between early secretory and pregnancy $(P<0.01)$ and late secretory and pregnancy $(P<0.001)$.

The proportions of granulated IELs (granulated IELs/CD45 + IELs) were $24.5 \%, 26.3 \%$, $46.4 \%$ and $100 \%$, respectively, for proliferative, early secretory, late secretory and early pregnancy endometrium. This reflects the increase in granulated IELs in the late secretory phase; all IELs in early pregnancy decidua were granulated, although absolute numbers of CD45 + IELs diminished. 

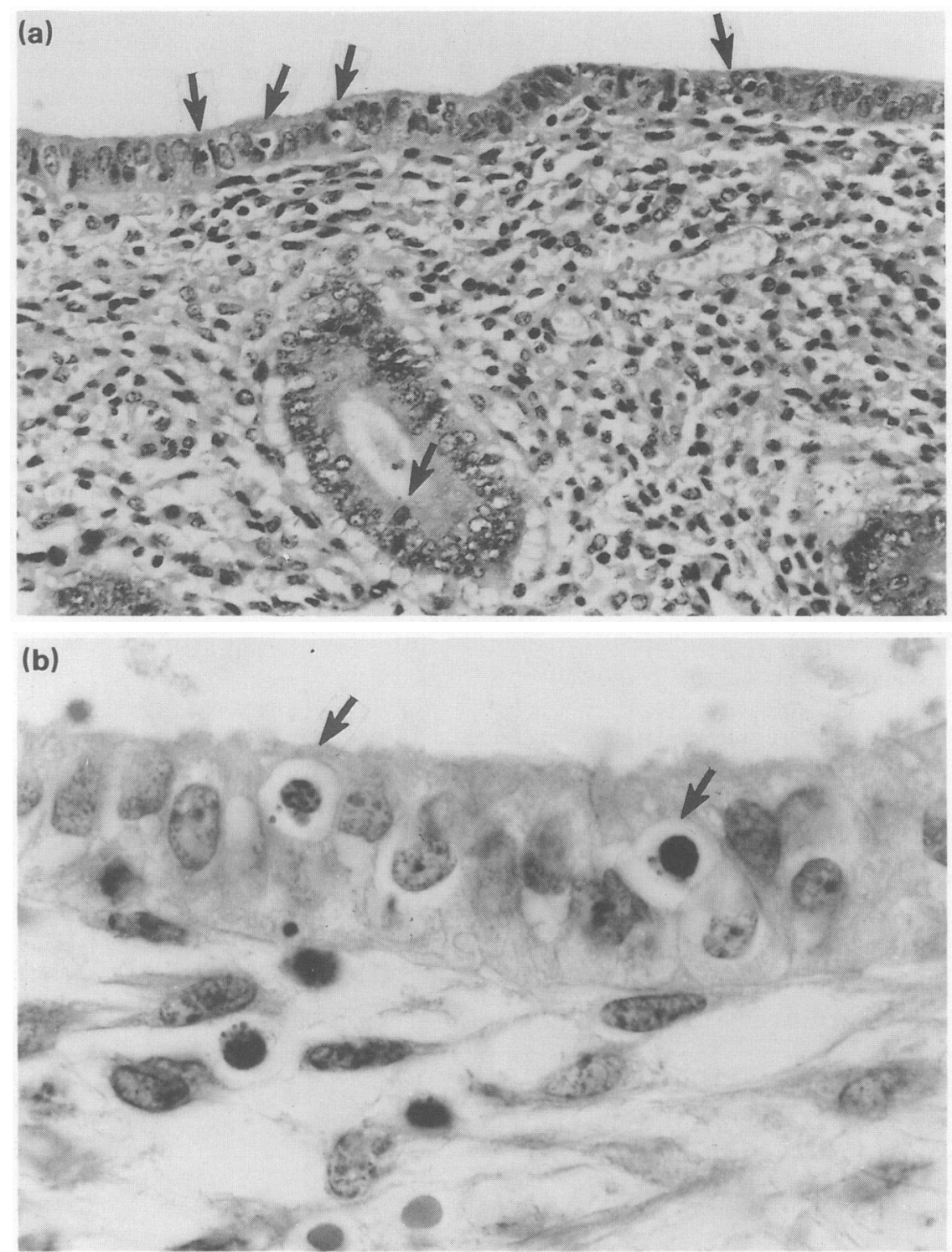

Fig. 1. Proliferative endometrium stained with (a) H \& E showing intraepithelial lymphocytes in surface and gland epithelium (arrowed), and (b) phloxine tartrazine showing two granulated IELs (arrowed) in surface epithelium. (a) $\times 160 ;($ b) $\times 1000$.

No significant difference in surface:gland IELs (Table 3) was found between proliferative and early secretory phases $(P>0.4)$ and early and late secretory phases $(P>0.3)$; late secretory-phase endometrium and early pregnancy decidua were similar $(P=1 \cdot 0)$. There was a greater difference between proliferative and late secretory phases $(P<0.06)$ and proliferative endometrium and early pregnancy decidua $(P<0 \cdot 1)$. Although not reaching statistical significance, these figures appeared to reflect greater numbers of surface IELs in proliferative endometrium, the surface:gland ratio diminishing as the cycle progressed to reach a ratio of approximately $2: 1$, in the late secretory phase and early pregnancy decidua. 


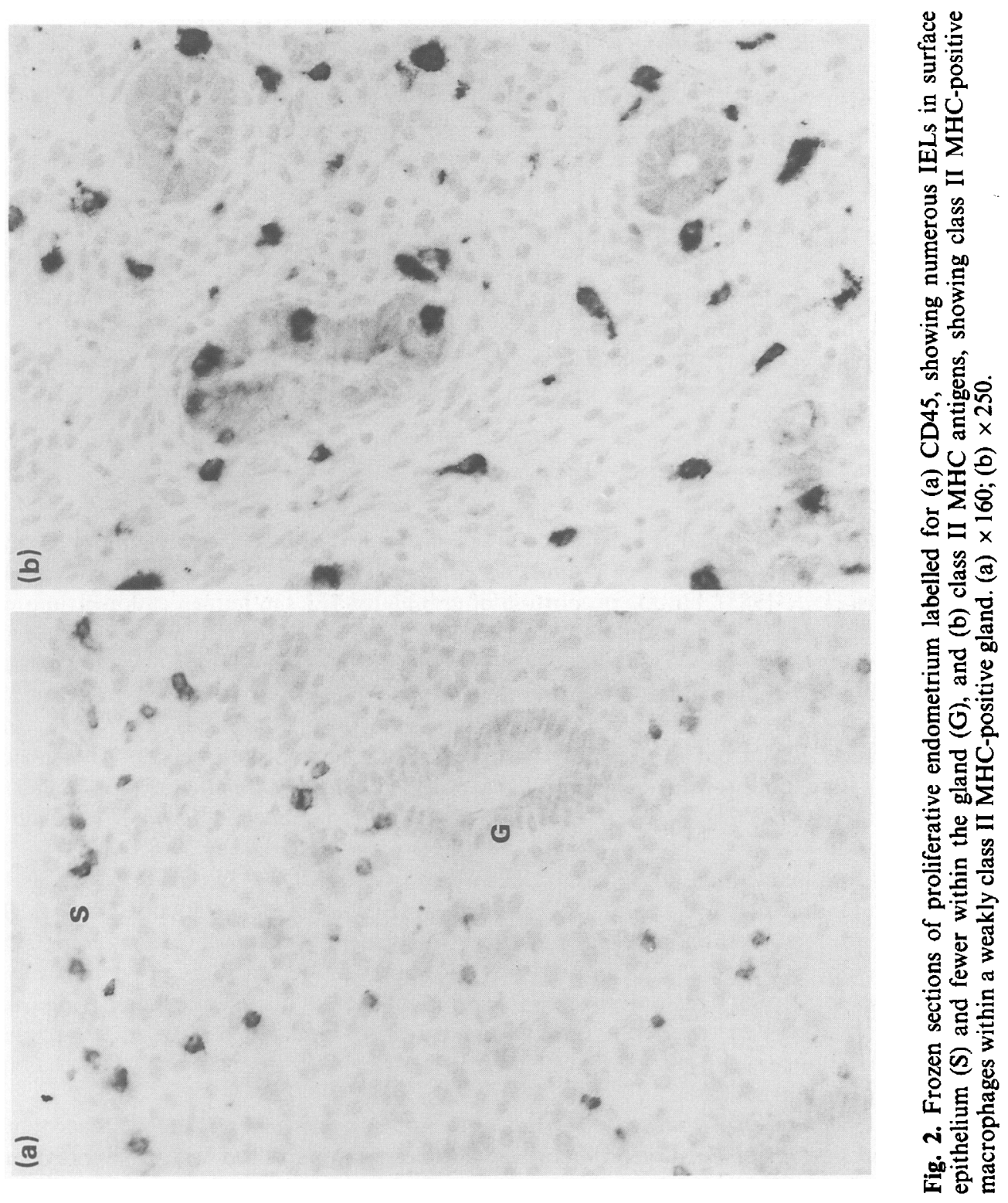


Table 3. Comparison of IELs in surface and gland epithelium

\begin{tabular}{lccr}
\hline Cycle stage & $\begin{array}{c}\text { No. of } \\
\text { samples }\end{array}$ & $\begin{array}{c}\text { Mean surface: } \\
\text { gland ratio }\end{array}$ & \multicolumn{1}{c}{ Range } \\
\hline Proliferative & 11 & $6 \cdot 19: 1$ & $1 \cdot 2-25: 1$ \\
Early secretory & 6 & $3 \cdot 11: 1$ & $0 \cdot 66-6 \cdot 5: 1$ \\
Late secretory & 6 & $1 \cdot 98: 1$ & $1 \cdot 0-4 \cdot 3: 1$ \\
$\begin{array}{l}\text { Early pregnancy } \\
\text { decidua }\end{array}$ & 7 & $1 \cdot 88: 1$ & $0 \cdot 45-3 \cdot 5: 1$ \\
\hline
\end{tabular}

\section{Frozen sections}

The results for frozen tissue are shown in Table 4, and examples of IELs labelled with the various mAbs are shown in Figs 3 and 4 . Significant differences between late secretory phase endometrium and early pregnancy decidua were found for CD2 $(P<0.03), \operatorname{CD} 56(P<0.09)$ and CD38 $(P<0.05)$, all three antibodies labelling a higher proportion of IELs in early pregnancy decidua compared with late secretory phase endometrium. No significant differences were found between $\mathrm{CD} 3, \mathrm{CD} 8, \mathrm{CD} 16$ and $\mathrm{CD} 22$ across the different stages of the cycle and early pregnancy.

\section{Discussion}

Granulated and non-granulated IELs are a component of mucosal-associated lymphoid tissue in human endometrium. The number of granulated IELs in human small intestine averages $24 \%$ (Cerf-Bensussan et al., 1985), but the proportion of granulated IELs in human endometrium was variable, ranging from $24.5 \%$ in proliferative endometrium, $46.4 \%$ in the late secretory phase and $100 \%$ in early pregnancy decidua. Granulated lymphocytes in human endometrial stroma are characterized by phloxinophilic cytoplasmic granules and a round, oval or indented nucleus and have previously been termed 'endometrial stromal granulocytes', 'Kornchenzellen', or ' $\mathrm{K}$ ' cells. Although formerly considered to derive from stromal cells and to secrete relaxin (DallenbachHellweg, 1981), immunohistochemical studies have indicated that they are phenotypically unusual granulated lymphocytes (CD2+, CD3-, CD16-, CD56+) (Bulmer et al., 1987; Ritson \& Bulmer, 1987).

Most IELs in human small intestine have been shown to be CD8 + T cells (Cerf-Bensussan et al., 1983, 1985). Previous investigations of endometrial IELs noted a majority of CD8 + T cells; NK cells were not reported although CD56 markers were generally not used (Morris et al., 1985; Kamat \& Isaacson, 1987; Marshall \& Jones, 1988). However, in a recent study of lymphocytes in non-pregnant endometrium CD56 + cells were observed infiltrating gland epithelium (King et al., 1989). Morris et al. (1985) reported a CD8:CD4 ratio of 4:1 and noted IELs in infant uteri. Variation in the number and phenotype of endometrial IELs with the menstrual cycle has not previously been documented.

The phenotype of IELs also varied according to menstrual cycle stage. CD3 + cells accounted for a higher proportion of IELs in proliferative endometrium comparied with early pregnancy decidua; in contrast CD56 + IELs were a substantially higher component in decidua than in proliferative endometrium. The increase in CD56 + IELs in early pregnancy decidua may partly account for the increased proportion of CD2 + and CD38 + IELs compared with late secretory phase endometrium. Nevertheless, a substantial component of IELs in first trimester decidua appears to be CD8 + T cells. Quantitation of CD45 + and granulated cells suggests that all IELs in early pregnancy decidua are granulated; these appear to fall into two main groups: CD3 + $/$ CD8 + and $\mathrm{CD} 3-/ \mathrm{CD} 56+/ \mathrm{CD} 38+$ lymphocytes. Granulated lymphocytes in human endometrial 

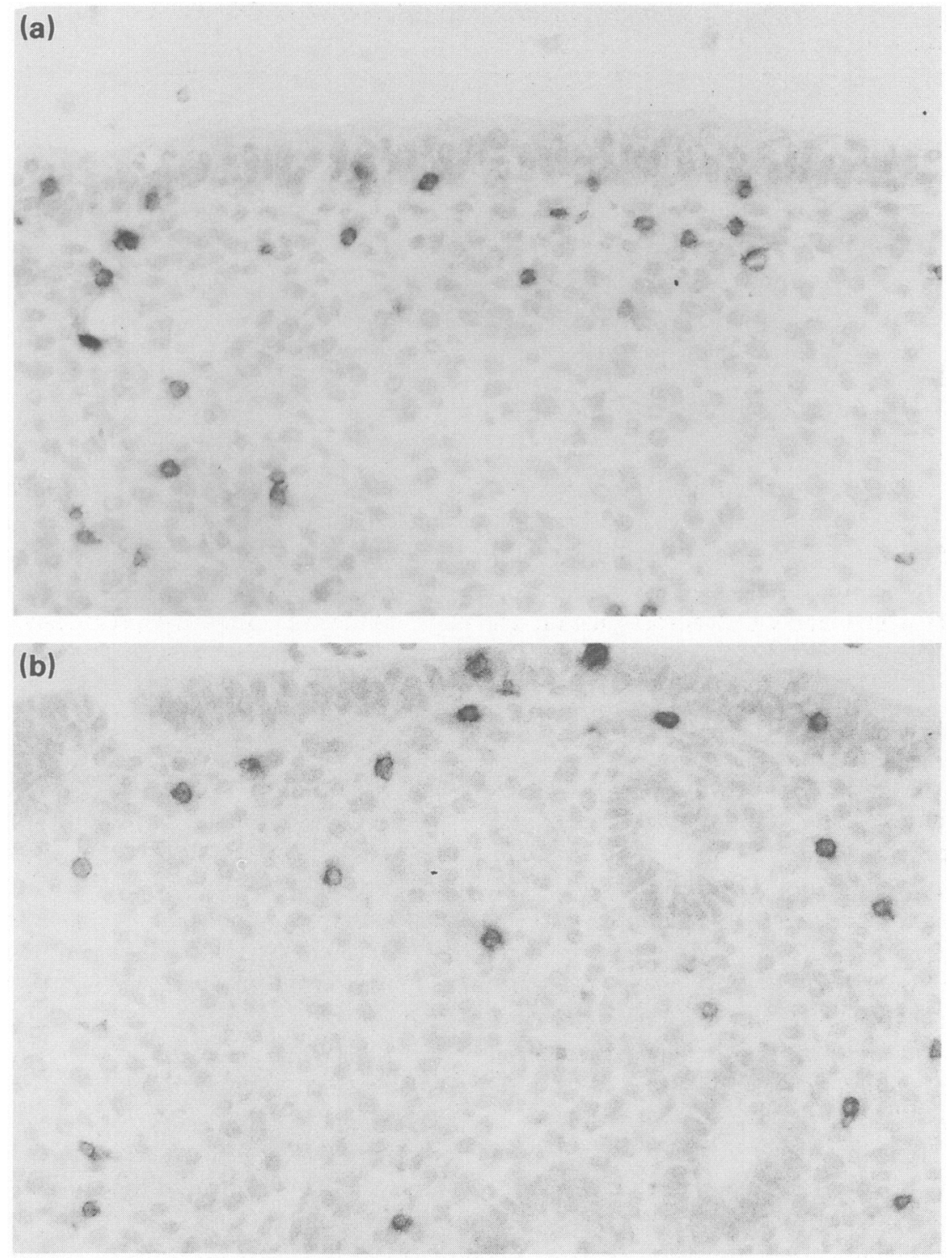

Fig. 3. Frozen sections of proliferative endometrium labelled for (a) CD3, and (b) CD8, showing several IELs in surface epithelium in (a) and (b) and none in gland epithelium in (b). $\times 160$.

stroma consist mainly of CD56+/CD3 - /CD2 \pm cells, CD3 + lymphocytes forming a relatively small proportion which varies according to menstrual cycle stage (Bulmer et al., 1988); the possibility that a proportion of $\mathrm{CD} 3+$ cells are granulated has not been excluded.

The presence of CD56- and CD38-reactive cells contrasts with IELs in human small intestine, which do not express the NK-associated antigens CD57 and CD11b (Cerf-Bensussan et al., 1983). Gastrointestinal IELs are thought to move between lamina propria and epithelium (Monk et al., 1988) and similar traffic between the epithelium and stromal lymphocytes may occur in endometrium. The differing leucocyte populations in endometrial stroma and small intestinal lamina propria could account for phenotypic distinctions between gut and endometrial IELs. Thus, there 




(b)

Fig. 4. Frozen sections of (a) proliferative endometrium labelled for CD38, and (b) early secretory endometrium labelled with Dako-T11. Both sections show a single positive IEL within gland epithelium and clearly situated above the basement membrane. $\times 400$.

is an intraepithelial compartment of an unusal granulated lymphocyte which is abundant in late secretory and early pregnancy endometrial stroma.

The number of endometrial IELs varied according to menstrual cycle stage. Geppert \& Geppert (1982) noted an increase in IEL numbers in the first trimester of pregnancy using H \& E and Giemsa stains. In the present study absolute numbers of IELs declined in early pregnancy decidua, partly due to loss of non-granulated IELs. This decrease may be due to cell death or to migration into surrounding stroma. Morris $e$ al. (1985) suggested that endometrial IELs migrate to lymphoid aggregates in basalis, and are replenished following menstruation. Both CD56 + and CD3 + cells may be observed in the basalis throughout the menstrual cycle (J. N. Bulmer, unpublished results). 
Table 4. Analysis of antigenic phenotype of endometrial IELs in frozen sections

\begin{tabular}{|c|c|c|c|c|c|c|c|c|c|}
\hline \multirow{2}{*}{$\begin{array}{l}\text { Cycle } \\
\text { stage }\end{array}$} & \multirow{2}{*}{$\begin{array}{c}\text { No. of } \\
\text { samples }\end{array}$} & \multicolumn{8}{|c|}{ Mean $( \pm$ s.e.m. $) \%$ positive cells } \\
\hline & & $\mathrm{CD} 8$ & $\mathrm{CD} 2$ & CD3 & CD56 & $\mathrm{CD} 16$ & $\mathrm{CD} 22$ & CD38 & CD25 \\
\hline Proliferative & 10 & $\begin{array}{r}33.6 \\
\pm 9 \cdot 3\end{array}$ & $\begin{array}{r}25 \cdot 8 \\
\pm 9.1\end{array}$ & $\begin{array}{r}29.2 \\
\pm 8.5\end{array}$ & $\begin{array}{r}11.3 \\
\pm 2.8\end{array}$ & $\begin{array}{r}11.5 \\
\pm 8.6\end{array}$ & $\begin{array}{r}2.7 \\
\pm 1.8\end{array}$ & $\begin{array}{r}43 \cdot 7 \\
\pm 9 \cdot 6\end{array}$ & $\begin{array}{l}0 \\
0\end{array}$ \\
\hline $\begin{array}{l}\text { Early/ } \\
\text { mid-secretory }\end{array}$ & 9 & $\begin{array}{r}22 \cdot 1 \\
\pm 5 \cdot 1\end{array}$ & $\begin{array}{r}25.2 \\
\pm 6.9\end{array}$ & $\begin{array}{r}25 \cdot 9 \\
\pm 6 \cdot 7\end{array}$ & $\begin{array}{r}13 \cdot 2 \\
\pm 3 \cdot 6\end{array}$ & $\begin{array}{r}16.9 \\
\pm 9 \cdot 2\end{array}$ & $\begin{array}{l}0 \\
0\end{array}$ & $\begin{array}{r}40.4 \\
\pm 7.7\end{array}$ & $\begin{array}{l}0 \\
0\end{array}$ \\
\hline Late secretory & 9 & $\begin{array}{r}27.7 \\
\pm 6.4\end{array}$ & $\begin{array}{r}20.2 \\
\pm 3.8\end{array}$ & $\begin{array}{r}16 \cdot 8 \\
\pm 5 \cdot 4\end{array}$ & $\begin{array}{r}13 \cdot 4 \\
\pm 4 \cdot 3\end{array}$ & $\begin{array}{r}7.2 \\
\pm 3.4\end{array}$ & $\begin{array}{l}0 \\
0\end{array}$ & $\begin{array}{r}34 \cdot 0 \\
\pm 10 \cdot 2\end{array}$ & $\begin{array}{l}0 \\
0\end{array}$ \\
\hline $\begin{array}{l}\text { Early pregnancy } \\
\text { decidua }\end{array}$ & 8 & $\begin{array}{r}39 \cdot 1 \\
\pm 13 \cdot 2\end{array}$ & $\begin{array}{r}46 \cdot 3 \\
\pm 10.0\end{array}$ & $\begin{array}{r}29 \cdot 9 \\
\pm 10 \cdot 9\end{array}$ & $\begin{array}{r}35.4 \\
\pm 10.7\end{array}$ & $\begin{array}{r}10 \cdot 4 \\
\pm 9 \cdot 7\end{array}$ & $\begin{array}{l}0 \\
0\end{array}$ & $\begin{array}{r}69 \cdot 0 \\
\pm 11 \cdot 3\end{array}$ & $\begin{array}{l}0 \\
0\end{array}$ \\
\hline
\end{tabular}

Furthermore mitotic activity has been documented in endometrial granulated lymphocytes in late secretory-phase endometrial stroma (Pace et al., 1989). Migration and proliferation of endometrial IELs may be under hormonal control. In-situ replication and migration of IELs has ben described in the gastrointestinal tract (Monk et al., 1988).

The ratio of IEL numbers in surface and gland epithelium varied at different cycle stages, with a greater proportion of surface IELs in proliferative and early secretory endometrium. Marshall \& Jones (1988) reported higher numbers of intraepithelial T cells in surface compared with gland epithelium but there was no variation with cycle phase. $T$ cells were 2.45 times more numerous in dome compared with crypt epithelium in appendix (Spencer et al., 1985).

The role of endometrial IELs is not known. Morris et al. (1985) suggested classical MALT functions; having detected antigen in columnar epithelium, endometrial IELs would migrate to basal lymphoid aggregates for amplification of the immune response and to regional and central lymphoid tissue. Kamat \& Isaacson (1987) suggested that endometrial IELs may regulate the immune response to implantation, although a similar role has been suggested for numerous other cell types. The detection of granulated IELs in human small intestine led to the suggestion that they may exhibit NK activity, as has been shown for large granular lymphocytes in peripheral blood (Timonen et al., 1981), but NK activity has not yet been documented, despite incubation with interferon $\gamma$ (IFN $\gamma$ ) and interleukin 2 (IL2)-containing conditioned medium (Cerf-Bensussan et al., 1985). NK activity has, however, been detected in IELs retrieved from mouse small intestine (Mowat et al., 1983; Klein \& Kagnoff, 1984). CD3-/CD56 + granulated lymphocytes separated from human first trimester decidua exhibit NK activity but are poor effectors compared with peripheral blood NK cells and NK activity was not enhanced by IFN $\gamma$ or IL2 (Ritson \& Bulmer,1989). There have to date been no functional studies of endometrial IELs but these cells are clearly worthy of further investigation.

We thank Birthright and the Yorkshire Regional Health Authority for financial support; Dr C. M. Steel for providing antibodies; and Dr P. J. R. Harkin for help with the statistical analysis.

\section{References}

Bienenstock, J., Johnson, M. \& Percy, D.Y.E. (1973) Bronchial lymphoid tissue. (1) Morphological characteristics. Lab. Invest. 28, 686-692.

Bulmer, J.N., Hagin, S.V., Browne, C.M. \& Billington, W.D. (1986) Localization of immunoglobulincontaining cells in human endometrium in the first trimester of pregnancy and throughout the menstrual cycle. Eur. J. Obstet. Gynecol. Reprod. Biol. 23, $3 !-44$.
Bulmer, J.N., Hollings, D. \& Ritson, A. (1987) Immunocytochemical evidence that endometrial stromal granulocytes are granulated lymphocytes. J. Pathol. 153, 281-288.

Bulmer, J.N., Lunny, D. P. \& Hagin, S.V. (1988) Immunohistochemical characterization of stromal leucocytes in nonpregnant human endometrium. Am.J. Reprod. Immunol. Microbiol. 17, 83-90.

Cerf-Bensussan, N., Guy-Grand, D. \& Griscelli, C. (1985) 
Intraepithelial lymphocytes of human gut: isolation, characterization and study of natural killer activity. Gut 26, 81-88.

Cerf-Bensussan, N., Schneeberger, E.E. \& Bhan, A.K. (1983) Immunohistologic and immunoelectronmicroscopic characterization of the mucosal lymphocytes of human small intestine by the use of monoclonal antibodies. J. Immunol. 130, 2615-2622.

Dallenbach-Hellweg, G. (1981) The normal histology of the endometrium. In Histopathology of Endometrium, 3rd edn, pp. 22-88. Ed. G. Dallenbach-Hellweg. Springer-Verlag, Berlin.

Geppert, M. \& Geppert, J. (1982) Lymphocytes in the epithelial layers of decidua and normal or abnormal endometrium. Archs Gynaecol. 233, 45-51.

Kamat, B.R. \& Isaacson, P.G. (1987) the immunocytochemical distribution of leucocytic subpopulations in human endometriun. Am. J. Pathol. 127, 66-73.

Kelly, J.K. \& Fox, H. (1979) The local immunological defence system of the human endometriun. J. Reprod. Immunol. 1, 39-45.

King, A., Wellings, V., Gardner, L. \& Loke, Y.W. (1989) Immunocytochemical characterization of the unusual large granular lymphocytes in human endometrium throughout the menstrual cycle. Human Immunol. 24, 195-205.

Klein, J.R. \& Kagnoff, M.F. (1984) Nonspecific recruitment of cytotoxic effector cells in the intestinal mucosa of antigen-primed mice. J. exp. Med. 160, 1931-1936.

Marshall, R.J. \& Jones, D.B. (1988) An immunohistochemical study of lymphoid tissue in human endometrium. Int. J. Gynecol. Pathol. 7, 225-235.

Monk, T., Spencer, J., Cerf-Bensussan, N. \& MacDonald, T.T. (1988) Stimulation of mucosal $T$ cells in situ with anti-CD3 antibody: location of the activated $T$ cells and their distribution within the mucosal microenvironment. Clin. exp. Immunol. 74, 216-222.

Morris, H., Edwards, J., Tiltman, A. \& Emms, M. (1985) Endometrial lymphoid tissue: an immunohistological study. J. clin. Path. 38, 644-652.
Mowat, A.McI., Tait, T.C., MacKenzie, S., Davies, M.D.J. \& Parrott, D.M.V. (1983) Analysis of natural killer effector and suppressor activity by intraepithelial lymphocytes from mouse small intestine. Clin. exp. Immunol. 52, 191-198.

Pace, D., Morrison, L. \& Bulmer, J.N. (1989) Proliferative activity in endometrial stromal granulocytes throughout menstrual cycle and early pregnancy. $J$. clin. Path. 42, 35-39.

Parrott, D.M.V. (1976) The gut as a lymphoid organ. Clin. Gastroenterol. 5, 211-228.

Patterson, J.A.K. \& Edelson, R.L. (1982) Interaction of T-cells with the epidermis. Br. J. Dermatol. 107, 107-122.

Ritson, A. \& Bulmer, J.N. (1987) Endometrial granulocytes in human decidua react with a natural killer (NK) cell marker, NKH1. Immunology 62, 329-331.

Ritson, A. \& Bulmer, J.N. (1989) Isolation and functional studies of granulated lymphocytes in first trimester human decidua. Clin. exp. Immunol. 77, 263-268.

Spencer, J., Finn, T. \& Isaacson, P.G. (1985) Gut associated lymphoid tissue: a morphological and immunocytochemical study of the human appendix. Gut 26, 672-679.

Sunderland, C.A., Redman, C.W.G. \& Stirrat, G.M. (1981) Monoclonal antibodies to human syncytiotrophoblast. Immunology 43, 541-546.

Timonen, T., Ortaldo, J.R. \& Herbermann, R.B. (1981) Characteristics of human large granular lymphocytes and relationship to natural killer and $\mathrm{K}$ cells. $J$. exp. Med. 153, 569-582.

Trejdosiewicz, L.K., Malizia, G., Badr-el-din, S., Smart, C.J., Oakes, D.J., Southgate, J., Howdle, P.D., Janossy, G., Poulter, L.W. \& Losowsky, M.S. (1987) $\mathrm{T}$ Cell and mononuclear phagocyte population of the human small and large intestine. Adv. exp. Med. Biol. 216A, $465-474$.

Received 4 April 1990 